\title{
Functional capacity of elderly people: implications for instrumental activities of daily*
}

\author{
Capacidade funcional de idosos: implicações para atividades instrumentais de vida diária
}

George Luiz Alves Santos ${ }^{1}$, Rosimere Ferreira Santana ${ }^{1}$

Objective: to describe the implications of social and cultural factors for instrumental activities of daily living of elderly people who participate of an interaction group. Methods: qualitative study, of ethno-nursing type, performed with 35 elderlies of a university extension project. Data collection was based on on-site observations, field journal and interviews. Analysis of the data was carried out in four phases proposed by ethno-nursing. Results: information technology, mobile telephones, accessibility to urban space, low education levels, as well as the slowness associated with the aging process influenced daily activities performance and impact on their functional capacity. Conclusion: cultural values and ways of life were expressed in daily habits that characterized the old way of being, a gerontology culture. Political, legal, friendship and social factors were described,

Descriptors: Nursing Care; Health of the Elderly; Geriatric Nursing; Culture.

Objetivo: descrever as implicações de fatores socioculturais para execução das atividades instrumentais de vida diária de idosos frequentadores de um grupo de convivência. Métodos: estudo qualitativo, do tipo etnoenfermagem, realizado com 35 idosos de um projeto de extensão universitária. Coleta de dados pautada em observações in loco, diário de campo e entrevistas. Análise dos dados realizada em quatro fases propostas pela etnoenfermagem. Resultados: domínio da informática, tecnologias como telefonia móvel, acessibilidade do espaço urbano, baixa escolaridade, bem como o processo de lentificação associados ao envelhecimento influenciaram a execução de atividades diárias, impactando na capacidade funcional. Conclusão: valores culturais e modos de vida foram expressos em hábitos diários que caracterizaram o modo de ser idoso, uma cultura gerontológica. Foram descritos fatores políticos, legais, de companheirismo e sociais.

Descritores: Cuidados de Enfermagem; Saúde do Idoso; Enfermagem Geriátrica; Cultura.

\footnotetext{
*Extracted from the dissertation "Processo de comunicação de idosos na execução das atividades instrumentais de vida diária: estudo etnográfico", Universidade Federal Fluminense, 2015.

${ }^{1}$ Universidade Federal Fluminense. Niterói, RJ, Brazil.

Corresponding author: George Luiz Alves Santos

Rua Dr. Francisco Portela, 2.266, Parada 40, CEP: 24435-135. Niterói, RJ, Brazil. E-mail: georgealvesrad@hotmail.com
} 


\section{Introduction}

To achieve independence in the community is one of the challenges in elderly people care, and for that, we can address the instrumental activities of daily living such as using the phone, using means of transport, going shopping, preparing meals, cleaning up, doing manual labor, handling medicine and managing their finances ${ }^{(1)}$. Some researches point out using the telephone, transport and handling money as the activities in which elderly people are more reliant ${ }^{(2)}$, which contribute to the current social representation of aging associated with physical decline and disability $^{(3)}$.

In the meantime, the culture emerges as an aspect to be considered because in a context of multifactorial care, ageing process is related to biological, psychological, social, cultural and spiritual factors. Therefore, considering the culture, values, beliefs, standards, ways of living learned, shared and transmitted that guide thoughts, decisions and actions of an individual and the society ${ }^{(4)}$, it may be possible to point out ways to cope and associate the autonomy and independence of elderly people to the aging process, looking for strategies of care. "As the elderly has some degree of dependence to manage financial resources or purchase basic consumer goods, their autonomy starts to be hampered. As a result, other people like formal or informal caregivers will manage their lives, make decisions for them, which results in a loss of identity"(5:826).

The functional capacity, autonomy and independence of elderly people to perform their daily activities are addressed using rating scales ${ }^{(2,5-6)}$. However, it is necessary to extrapolate the assessment of autonomy and independence performing such activities, and ponder the real contexts which do not admit a scale application.

Geriatric care should consider the worldview, values, beliefs and care practices of elderly people in their daily life, which makes it possible to provide culturally congruent care ${ }^{(4.7)}$, in which actions will be meaningful and based in the reality and the context of every senior citizen life, since culture influences in people's ways of living, including preferences, feelings, and meanings assigned to their experiences ${ }^{(8)}$.

As an intervention strategy, nurses can use interaction groups of elderly people where feelings and affections are shared, and fear, insecurity, depression, especially after the loss of loved ones and family members are reduced. They are also places to exchange life experiences, friendship, that impact on mental health and physical well-being. These environments allow them to ease the loneliness, interact with people and find an activity that brings sense to their lives ${ }^{(9)}$.

These groups are mediated by the interaction where participants can expose difficulties and strategies of solving the everyday demands of life, spaces in which nurses can access for social exchanges and observe how elderly people perform instrumental activities of daily living.

Thus, understanding how elderly people perform these activities in real environments, and not only through the application of scales, can guide to more assertive actions and group activities in the light of the living reality, with a great contribution of Gerontological nursing in the context of interaction groups. The construction of knowledge in this field can help training in gerontological nursing, aligned with the actual demands of elderly people, articulating theoretical and practical issues in the construction of knowledge.

By consolidating the field of knowledge and expertise of nurses in gerontology through research can contribute to autonomy with social visibility and quality. Thus, the objective was to describe the implications of social and cultural factors for instrumental activities of daily living of elderly people who participate of an interaction group.

\section{Methods}

This is a qualitative research, ethno-nursing type, held between November 2013 and September 
2014. The scenario was an interaction group of elderly people, developed in an extension project of a public University in the city of Niterói, Rio de Janeiro, a common environment for the researchers since they had developed extension activities and research there before.

35 elderly people were selected by convenience, maned as key informants ${ }^{(4,7)}$. Those who had participated for at least one year in the project activities on a regular basis and were available to attend the scheduled interview, were included. The exclusion criteria were: missing two scheduled meetings; cancelling or do not show up at the extension project. Seven professionals who worked in the extension project were the general informants ${ }^{(4.7)}$. including those who had full degree; acted in the workshops of the extension project directly or coordinating them; develop research activities; and worked as administrative technicians in the project. Interns and scholars were excluded but acted as a support in the project, and the who missed the scheduled meeting twice were also excluded. Key informants were identified by codes IC1... IC35. The key informants were encoded as IG1-IG7.

Data collection was based in the Observation-Participation-Reflection (O-P-R) model; and field journal and interviews with key and general informants were used, following the four steps of the method ${ }^{(4.7)}$. Step 1 consisted on initial observation in the extension project (entrance in the field, notes in initial field journal); selection of the first key informants in the extension project; recognition interview (based on the theoretical and methodological: theory diversity and universality of culture care) ${ }^{(4)}$ and research issues, with 60 minutes long approximately, fully recorded and transcribed.

Step 2 continued the observation in the extension project (notes in field journal); selection of more key informants in the extension project; in-depth interview also based on the theory of diversity and universality of culture care ${ }^{(4)}$ with key informants and research questions, with an average duration of 60 minutes, fully recorded and transcribed; selection of environments different from the extension project in which the elderly people usually performed instrumental activities of daily living; and interviews with key informants.

Step 3 continued the observations in the extension project (with field journaling); observation in shopping malls, banks, supermarkets and public transport (with field journaling). And, finally, as the last stage of data collection, that is, step 4, thematic meeting with the elderly people was scheduled to confront, verify and validate the findings as well as to confirm and identify new research themes. Multimedia resources were used to project images representing the issues to be discussed. That stage lasted 2 hours, and included the participation of 30 elderly people of the extension project.

The analysis was based on ethno-nursing ${ }^{(4)}$, also divided into stages. In step 1, named collection, description and documentation of raw generated data and the first reading of all the material produced was realized; we also organized and took notes of the first impressions. In step 2, we identified the descriptors and components as well as the recurring themes in the interviews transcribed; the daily records of field journal were grouped in common and recurring themes; data was analyzed looking for similarities and differences between the subjects, grouping similar findings.

In step 3, pattern and textual analysis and material reading continued; greater common themes were captured; we gathered them in thematic units, approaching the major research themes. And, finally, in step 4, research themes, results, theoretical formulations and recommendations were summarized and the interpretation of the findings produced as a follow-up of the three previous steps; the abstraction and confirmation of great themes, research results and theoretical recommendations occurred. 
The study complied with the formal requirements contained in the national and international regulatory standards for research involving human beings.

\section{Results}

With regard to socio-demographic variables all 35 elderly people, we identified that $82.9 \%$ were female; $52.3 \%$ were between 70 and 79 years old; $57.1 \%$ were retired; $31.3 \%$ with an income up to two minimum wages; and $28.1 \%$ with an income of more than three minimum wages. About schooling, 48.6\% reported having finished elementary school.

About their health situation, non-communicable chronic diseases were prominent, as $52.6 \%$ suffered high blood pressure. The cardiologist was quoted as a reference for health monitoring by $55.5 \%$. The prevalent special need was vision problems since $82.4 \%$ wore glasses.

With regard to activities developed in the extension project, the most attended workshops were: Cognitive memory (35; 27.5\%); Falls prevention project (29; 22.8\%); Citizenship (11; 18.6\%); and IT (5; $3.9 \%)$.

Through analysis, it was possible to identify two major themes represented by the categories: longevity culture in instrumental activities of daily living, the use of technology in instrumental activities of daily living: uses and possibilities and synthesis of results from the Sunrise Model of Madeleine Leininger.

\section{The longevity culture in instrumental activities of daily living}

Among the respondents, it was possible to identify a common way of being old, a culture of aging, where retirement as a fix income source, gives the elderly more free time and time flexibility; access throughout the week to environments of instrumental activities of daily living; the elderly even justify they go many times to the market due their physical demands as they said they cannot carry much weight and therefore the shopping must be divided in smaller portions; as well as they occupy their time and socialize: I don't have a fix time for my activities, I'm on the street, I need something, I go into the market and buy, because I cannot pick up weight, I can't buy a lot of things at the same time (IC31). I don't have fix time, I see my work at home, what I do, my stuff, I do what I feel like, it depends on my mood, what is more convenient for me. I don't have a fix time for doing things, except going to the doctor (IC29).

In the context of interpersonal relationships, the recognition or not of the elderly as a citizen was mentioned as an influence of the interactions in instrumental activities of daily living: Everyone respects me and now I'm with my cane and I say it's charming. But it's not the stick. It is because it gives me some security and people respect me more, because I always treat others nicely, and if I have elderly rights, I don't need to talk (IC17). So far I didn't need to enforce my rights, but if I need it, I will complain, because it is my right (IC15).

Also, the presence of non-elderly people using priority queues was a factor mentioned by respondents as an example of disrespecting their rights: Sometimes, I go to the old people queue and then a seventeen, twenty-year-old comes and passes in front of me, and I keep quiet, I accept because I don't want to complain and create a problem, it will be horrible (IC24). In the market, there are cashiers for the elderly or for small purchases, but others let's say, raunchy people, put their shopping cart there, taking our time (IC26).

The use of priority queues was linked to convenience, or even to the number of elderly people in those places, showing how the elderly used and enjoyed their acquired rights: Sometimes, the queue for the elderly is a little smaller than the normal queue, then old people like me, it's complicated to sort things out, it is slow, then I stay there on the other queue for non-elderly, the service is faster, because the guy that is not old is agile (IC22). If there are only a few old people, I use it, but I like to use the other queue that is faster, there are more cashiers, and there's only one for old people (IC30).

Another factor that limited the instrumental activities of daily living was the urban environment that sometimes is not adapted for older people to move 
and free access to the environments of daily activities: The streets are full of holes (IC14). Unfortunately, the streets and the sidewalks are not well-maintained. In the malls is better, because there are escalators that ease a lot... supermarkets still need to improve accessibility to the elderly (IC3).

Public transportation in the city of the research had some structure adaptations, which allowed, according to the elderly, a better access, favoring leaving home to perform instrumental activities of daily living: In Niterói, buses have straighter steps, flatter so we can go up, that helps a lot. I've already slipped, fell on buses because of high steps (IC27).

The interviews with the professionals who worked on the project, namely, general informants showed some findings such as slowness, that was mentioned as a factor that influences instrumental activities of daily living, because they considered that the accelerated pace of the current world, with relationships that look to be objective and optimize time, requires greater adaptation of the elderly to environments where their activities are performed: I think it's a matter of time, when the person gets older, everything is slower, so the society today is like flash, everything is fast, ... so it's not just a question of technology in the various spaces, but also the difficulty of listening, all the elderly has a story to tell, and I think that hampers communication (IG1).

Also, the low level of schooling appears as a factor that limits the access to goods and services. The difficulty arises to express themselves and make them understood: Due to their basic education, they have difficulty expressing a problem they want to solve and who usually tries to understand them don't have a lot of patience, or is not prepared to deal with the elderly (IG3). The main cause of difficulty would be the low educational level, the fear of communication, whether they will be understood or not (IG5).

About the priority seats, we identified in the comments regarding public transportation that the elderly expected a recognition of their rights, and people to offer them the seat: In a trip using public transportation it was crowded and all seats occupied, ordinary people used the prio- rity seats, when there was an elderly person, or even another person who needs priority seats, the place was offered. In a moment of the trip another elderly person came, at the time there was a priority place occupied by a teenage girl who, even with the old man approaching and looking right at her insistently, did not offer the place, the elderly seemed dissatisfied nodding his head several times (Note from the researcher field journal - Niterói, 23 July 2014).

\section{Use of technologies in instrumental activities of daily living: uses and possibilities}

In this category we could identify the use of technologies by the deponents in instrumental activities of daily living. From the findings emerged these facts: adapted elderly people, internet and virtual environment users to solve the demands of daily life, while others run counter and are resistant to the use of technology: I go to the bank to pay and don't use anything on the computer to avoid revealing individual records and identity. I don't pay anything on the computer (IC30). Tablet, computer, tv with HD ... of course, I cannot live without them, I pay everything on the internet but prefer ATM. I try to be updated, yes, because I do not want to be isolated (IC28).

Knowledge about technology and the internet generated a feeling of wellbeing with the new possibilities, extending, for example, their family interaction: I am learning IT ... I've got email, I have a computer, I can communicate with my friends or acquaintances through the internet, send messages to my niece who lives in the United States and she sends to me (IC5).

About how to manage the difficulties, they pointed out some strategies such as asking a relative or even a neighbor to help using technologies to solve issues related to financial life in the context of the domestic environment: My phone I say it is just to talk and listen. My computer, I have a lot of restriction, when I'm lost I pick up the intercom and say: Neighbor, help! And he helps me (IC6). I have no difficulty, if you need to make an account I do it manually, because I don't know how to deal with this machines, and other things that need to do in the computer, my son, my grandson do them for me (IC31). 
As for the non-domestic environment, the elderly stated they rely on the professionals of the establishments to use of technologies or services: Bank, ATMs, I call someone at the Bank who can help me and never denied help (IC12). At the Bank, I ask for help to the officials, to the seller in the shop, to the cashier at the supermarket (IC18).

Manipulating and learning about new devices with touch screen technology, for example, seem to hinder or even impair the use of mobile telephony by elderly people. As general informants observed, the conventional phones were more frequently used: often, using a phone, to know how to use technology, sometimes here (in the project) they ask me, 'you see this here for me, "How do I do that?" to manipulate their cell phones to help (IG4).

Although some difficulties using technologies were identified, they recognized themselves as senior citizens using them, or even trying to use them, possibly overlooking adaptation and learning, or even to maintain their autonomy to perform their instrumental activities of daily life.

\section{Synthesis of the results from the Sunrise Model of Madeleine Leininger}

The theory of culture care diversity and universality has its main concepts in a structured diagram Sunrise Model - a cognitive map that allows nurses to identify the information needed to establish the cultural care, that is the higher and more abstract level of the diagram. The diagram is not the theory, but a way of making it ${ }^{(4.7)}$. From the original Sunrise Model, we prepared the findings of the study synthesis.

We identified a low educational level; low income was an economic factor considered; as political and legal factors, we identified the citizenship workshops, which resulted in the acquisition of knowledge about the rights of the elderly, making them more aware of their rights. About priority seats, the respondents mentioned the elderly rights were not re- cognized; in priority queues, young people use them and sometimes disregard the presence of the elderly, which was identified in queues and observed in spaces of instrumental activities of life; public transport is still not adapted to the specificities of the elderly.

The technological factors pointed out the difficulties to use and learn information technologies and communication, and I.T workshops gives them the possibility of learning; the knowledge on the use of technologies brings a feeling of well-being and new possibilities of coexistence and social interaction; They showed a lack of confidence using virtual environments to solve demands of daily life, and they have to ask for support and assistance to their family, friends, neighbors and professionals in the use of technologies.

The interaction group was identified as a possibility of acquiring knowledge, learning new skills, socializing and sharing difficulties and experiences; family and the interaction group were mentioned as supports for the demands of daily life as examples of friendship and social factors. Considering cultural values and ways of living, we understood that young people are sometimes seen as more agile in instrumental activities of daily living; the elderly look for adaptation to their body that gets old; they mentioned a slowness processes and the perception of the elderly as "slow" on their daily activities, compared to the general population.

\section{Discussion}

The findings of the research do not allow generalizations, because it is a group of only 35 elderly people that shows a particular reality. Furthermore, in a study of qualitative nature, the answers reflect the individual experiences and places. However, some research topics can help to describe how the factors discussed in the study involve instrumental activities 
of daily living in other interaction groups.

Among elderly people who participate in the research, we identified difficulties in the use of cell phones and the need to go the market many times, as they cannot carry much weight. Another study supports our findings: it was conducted with 1,593 elderly people and identified a more frequent need of help to use the telephone (11.0\%) and do the shopping (10.3\%). As for the use of the telephone, the demand for aid was a common finding in which the largest functional incapacity was linked to a lower school level ${ }^{(10)}$.

We can also point out the association between functional incapacity to instrumental activities of daily living and variables such as "age, education, religion, occupation, family and individual income, alcoholism, sleep and rest and health self-assessment which presented an increased risk of outcome"(11:115).

About group activities, the respondents had a weekly schedule of events and engagement in different activities which helps to maintain the functional capacity, since mental and physical inactivity are factors that accelerate the functional decline of the elderly ${ }^{(12)}$.

The respondents mentioned "feeling qualm about using the queue for old people", that is a prejudice among the elderly people. When performing activities related to their financial life management, as payments, typing passwords, use of credit and debit cards, as well as handling money, some elderly people are considered "slow". It must be taken into account, however, that elderly's memory suffer decline so other activities that require a high degree of concentration can also change and there is no doubt that the performance on multiple tasks or the coordination of two tasks at the same time suffer the age interferen$\mathrm{ce}^{(13)}$. Changes in visual acuity as well as non-adapted equipment can promote a slow performance.

In the observed environments, machines for card payments, as well as the size of numbers for typing passwords were the same as for the general population. Considering the specific characteristics of the elderly, such as those of the population of this study like low education and vision changes, the findings can be taken as difficulties in the process of their activities implementation, resulting in loss or reduced functional capacity. It is considered that learning information technology could reduce the need for help to use banking, social security and trade services, and enables to look after their personal interests on their own, and IT knowledge, even the basic, would make the elderly more independent ${ }^{(14)}$.

However, low educational level, common finding among the respondents, may result in difficulties to learn about technologies, which favors the maintenance of partial or total dependence on issues such as the use of banking, in which the passwords are often alphanumeric composition.

Computer workshops are a useful strategy in this context, facilitating learning, although the elderly people in this research did not significantly participated in this kind of group activity. The literature shows typing, printing documents, mouse handling, the use of the internet, access to e-mail, communication, downloads and recording in digital media and Flash drives as difficulties that influence in the use of computers ${ }^{(15)}$. Similarly, Literacy workshops would be useful and associated with the information technology could maximize the functional capacity.

In priority queues, the number of elderly people was crucial in the decision of using them or not, as pointed out by the respondents. The elderly said the queues that are not priority, "are" faster, so the idea that senior citizens are not adapted to perform essential actions is reinforced in their speech. It was also observed the presence of young people in the priority queues; sometimes the elderly people complained and showed dissatisfaction. However, it was common the presence of old people in not priority queues.

In the city observed, there is adapted public transportation with lowest steps, but that's not the 
reality of all the vehicles, and so the elderly is still exposed to falls. "Most of the buses used in Brazil do not meet the needs of the elderly population. The height of the steps hampers elderly people to get on and off the bus, as well as the terrible facilities and bus drivers' service such as: impatience with mobility difficulties, indiscriminate occupation of the seats reserved for the elderly person and accidents caused because of drivers' lack of attention and care. It is essential that the elderly have enough time to get on, pay, sit and enjoy a quiet atmosphere inside the vehicle"(16:92).

About priority seats on public transportation, the respondents reported that sometimes, users pretend to sleep and ignore the presence of the elderly. That was repeated in the observations. Considering the elderly as a citizen who necessarily belongs to a society and is built in it as a subject and, subsequently, is valued as a human being in their rights and duties in civil, social and political spheres ${ }^{(17)}$, can generate the feeling of belonging and well-being. In this regard, the historical and social construction itself can explain such an attitude, "from the beginning, old age has always been associated with diseases, losses and limitations, under the influence of the biomedical model, which stigmatizes this phase as a period of decay and loss. Unfortunately, even today, this negative view is confirmed"(18:17).

With regard to accessibility and mobility in the urban space, according to the participants, the sidewalks, for example, are not well-maintained and favor falls. The urban environment adapted to the elderly reality should imply accessibility to environments where instrumental activities of daily living are carried out, favoring their social life. Falls can expose the elderly to physical damage, such as tissue injuries, wounds and fractures, functional decline and increased dependence, in addition to psychosocial issues involved, such as fear of falling, isolation and loss of autonomy ${ }^{(19)}$.
They try to carry out activities in groups since they provide better health and living conditions, physical activities improve the quality of life in aspects related to physical and mental health, sharing joys, sorrows and knowledge ${ }^{(9)}$. These spaces minimize illness as a result of loneliness, sadness, helplessness or lack of communication ${ }^{(18)}$. Therefore, the elderly care must be based on a relationship grounded on interaction, which will determine the success or failure of therapies, in which bonds construction and trust are crucial $^{(20)}$.

\section{Conclusion}

Cultural values and ways of living were expressed in daily habits that characterized a way of being elderly, a gerontology culture. Political and legal factors might be described since they mentioned rights and, sometimes, disrespect to them by non-elderly population, as in the use of public transport. These conflicts also pointed to friendship and social factors when considering the intergenerational relations.

\section{Collaborations}

Saints GLA and Santana RF contributed in the design and project or analysis and interpretation of data, article writing, relevant and critical review of intellectual content and final approval of the version to be published.

\section{References}

1. Viveiro LAP, Almeida AS, Meira DM, Lavoura PH, Carmo CM, Silva JM, et al. Declínio de atividades instrumentais de vida diária associado à perda de força de preensão palmar em idosos internados em enfermaria geriátrica. Rev Bras Geriatr Gerontol [Internet]. 2014 [citado 2017 Ago 24]; 17(2):23542. Disponível em: http://www.scielo.br/pdf/ rbgg/v17n2/1809-9823-rbgg-17-02-00235.pdf 
2. Sousa SS, Oliveira PS, Oliveira FS, Holanda MA, Almeida PC, Machado AL. Estudo dos fatores sociodemográficos associados à dependência funcional em idosos. Rev Enferm UFPI [Internet]. 2013 [citado 2017 Jul 6]; 2(1):44-8. Disponível em: http://www.ojs.ufpi.br/index.php/reufpi/ article/view/907/pdf

3. Missias MR, Santos CE, Couto ES, Teixeira JR, Souza, RM. Qualidade de vida, saúde e política pública de idosos no Brasil: uma reflexão teórica. Rev Kairós [Internet]. 2013 [citado 2017 Jul 6]; 16(2):27-38. Disponível em: http://revistas.pucsp.br/index. php/kairos/article/view/17629/13128

4. Leininger MM, McFarland MR. Culture care diversity and universality: a worldwide theory of nursing. Sudbury: Jones and Bartlett Publishers; 2006.

5. Kagawa CA, Corrente JE. Analysis of elderly functional capacity in the municipality of Avaré, São Paulo: associated factors. Rev Bras Geriatr Gerontol. 2015; 18(3):577-86. doi: http://dx.doi. org/10.1590/1809-9823.2015.14140

6. Santos GS, Cunha IC. Avaliação da capacidade funcional de idosos para o desempenho das atividades instrumentais da vida diária: um estudo na atenção básica em saúde. Rev Enferm Cent 0 Min [Internet]. 2013 [citado 2017 Jul 6]; 3(3):820-8. Disponível em: http://www.seer.ufsj. edu.br/index.php/recom/article/view/421/528

7. McFarland MR, MixerSJ, Alamah HB. Ethnonursing: a qualitative research method for studying: culturally competent care across disciplines. Int J Qual Meth [Internet]. 2012 [cited 2017 Jul 6]; 11(3):259-79. Available from: http://ejournals. library.ualberta.ca/index.php/IJQM/article/ view/8986/1413

8. Chibante CL, Espírito Santo FH. A etnografia na pesquisa em enfermagem: uma revisão integrativa. Cul Cuid [Internet]. 2014 [citado 2017 Jul 6]; 18(40):99-106. Disponível em: https://rua. ua.es/dspace/bitstream/10045/43946/1/Cultura-Cuidados_40_13.pdf
9. Wichmann FM, Couto AN, Areosa SV, Montañés MC. Grupos de convivência como suporte ao idoso na melhoria da saúde. Rev Bras Geriatr Gerontol [Internet]. 2013 [citado 2017 Jul 6]; 16(4):821-32. Disponível em: http://www.scielo.br/pdf/rbgg/ v16n4/1809-9823-rbgg-16-04-00821.pdf

10. Nunes JD, Saes MO, Nunes BP, Siqueira FCV, Soares DC, Fassa MEG, et al. Indicadores de incapacidade funcional e fatores associados em idosos: estudo de base populacional em Bagé, Rio Grande do Sul. Epidemiol Serv Saude. 2017; 26(2):295304. doi. http://dx.doi.org/10.5123/S167949742017000200007

11. Pereira LC, Figueiredo MLF, Beleza CMF, Andrade EMLR, Silva MJ, Pereira AFM. Predictors for the functional incapacity of the elderly in primary health care. Rev Bras Enferm. 2016; 70(1):1128. doi. http://dx.doi.org/10.1590/0034-71672016-0046

12. Reis LA, Reis LA, Torres GV. Impacto das variáveis sociodemográficas e de saúde na capacidade funcional de idosos de baixa renda. Cienc Cuid Saúde. 2015; 14(1):847-54. doi. http://dx.doi. org/10.4025/cienccuidsaude.v14i1.19585

13. Mascarello LJ. Memória de trabalho e processo de envelhecimento. Psic Rev São Paulo [Internet]. 2013 [citado 2017 Ago 24]; 22(1):43-59. Disponível em: https://revistas.pucsp.br/index. php/psicorevista/article/view/16657/12515

14. Vieira LJ, Silva TA, Barbosa ACG, Garcia MCM. As tecnologias de informação e comunicação na inclusão de cidadãos da terceira idade. An SULCOMP [Internet]. 2016 [citado 2017 Ago 17]; 8. Disponível em: http://periodicos.unesc.net/ sulcomp/article/view/3124/2854

15. Loli MC, Maio ER. Uso da tecnologia por idosos: perfil, motivações, interesses e dificuldades. Rev Educ Cult Soc [Internet]. 2015 [citado 2017 Jul 6]; 5(2):211-23. Disponível em: http://sinop.unemat. br/projetos/revista/index.php/educacao/ article/viewFile/1864/1488 
16. Oliveira AG, Souza ML, Karnikowski MG, Taco PW, Motta RA. Direitos dos idosos relacionados à sua mobilidade. Rev Transp Pública [Internet]. 2012 [citado 2017 Jul 6]; 34:1. Disponível em: http:// docplayer.com.br/15605363-Direitos-dosidosos-relacionados-a-sua-mobilidade.html

17. Santos EB, Silva RR, Oliveira LA. Doenças crônicas não transmissíveis e a capacidade funcional de idosos. Rev Pesqui Cuid Fundam On line. 2014; 6(2):516-24. doi. http://dx.doi. org/10.9789/2175-5361.2014v6n2p516

18. Meneses DL, Silva Júnior FJ, Melo HS, Silva JC, Luz VL, Figueiredo ML. A dupla face da velhice: o olhar de idosos sobre o processo de envelhecimento. Enferm Foco [Internet]. 2013 [citado 2017 Jul 6]; 4(1):15-8. Disponível em: http://revista. portalcofen.gov.br/index.php/enfermagem/ article/view/495/185
19. Pereira GN, Morsch P, Lopes DG, Trevisan MD, Ribeiro A, Navarro JH, et al. Fatores socioambientais associados à ocorrência de quedas em idosos. Ciênc Saúde Coletiva. 2013; 18(12):350714. doi: http://dx.doi.org/10.1590/S141381232013001200007

20. Agreli HF, Peduzzi M, Silva MC. Atenção centrada no paciente na prática interprofissional colaborativa. Interface. 2016; 20(59):905-16. doi: http:// dx.doi.org/10.1590/1807-57622015.0511 